\title{
OPTIMIZATION OF CULTIVATION CONDITIONS OF BACILLUS GENUS BACTERIA FOR PROTEOLYTIC ENZYMES PRODUCTION
}

\author{
IELYZAVETA BARSKA \\ National Aviation University, Kyiv
}

The spectrum of economically viable protein substrates that can be used in production of proteolytic enzymes was determined. Based on the experimental data component's composition of the nutrient medium was optimized. The maximum proteolytic activity of the genus Bacillus bacteria was determined in the case of their incubation for 72 hours at temperature $37{ }^{\circ} \mathrm{C}$ on a medium with concentrations of wheat bran protein $-1,42 \%$ and wheat flour protein $-1,58 \%$.

Key words: bacteria Bacillus, substrates, wheat bran, whole-wheat flour, proteolytic enzymes, optimization.

Introduction. Poteolytic enzyme, also called Proteinase, any of a group of enzymes that break the long chainlike molecules of proteins into shorter fragments (peptides) and eventually into their components, amino acids. Proteolytic enzymes are present in bacteria and plants but are most abundant in animals [1].

Protease production depends on the producer strain and culture medium. To get productive enzyme is necessary to optimize the culture medium in many ways. Environments for receiving protease typically contains a source of carbohydrates starch, lactose, and a nitrogen source - soybean meal, casein, corn steep liquor. Carbohydrates are essential for the duration of cultivation. It is important to maintain a constant, but a low concentration of carbohydrates, because the high concentration represses the production of the enzyme. Free amino acids repress production of the enzyme, while the presence of peptides and proteins in the medium induce. To obtain a protease suggested using deep and shallow cultivation [2]. 
Simple and economical methods of cultivation of the surface can be used to produce proteases (acidic, alkaline and neutral). The main producers - Aspergillus, Mucor, Penicillium, and Rhizopus. As substrates in addressing various agroothody, but most research suggests that the best solution of the enzyme is achieved by using wheat bran. Comparative studies show that in obtaining the alkaline protease (Bacillus amyloliquefaciens ATCC 23844), the amount of enzyme with 1 gram bran with surface cultivation is equivalent to $100 \mathrm{ml}$ of liquid medium in submerged cultivation. Protease synthesis is also repressed by a high concentration of carbohydrates [4].

The important parameters that influence the large-scale production using surface cultivation protease, is the density and thickness of the substrate. When cultured in the medium output trays protease low. This is associated with dry substrate. This can be avoided by using rotary drum fermenters. Most preferred fermentors with aeration and filtration sensors monitoring temperature and humidity. The maximum yield of protease was recorded using Bacillus amyloliquefaciens [5].

The same method is described submerged culture on the membrane surface. The essence of the method consists in growing mycelium on a membrane carrier, which is in contact with the liquid medium. This method allows you to control the $\mathrm{pH}$ and the concentration of the enzyme facilitates extraction methods. In applying this method, using Aspergillus oryzae IAM 2704, was received protease yield up to 2-fold compared with the surface, and 10 times higher than in submerged culture [6].

Extracellular proteases produced, so their selection using distilled water or buffer solutions. To get clean of drugs used deposition methods salts or solvents to further purification by chromatographic methods or electrophoresis.

Offered a lot in detection of protease activity. The most common are the various modifications of the classical method of Anson [3]. 
Basic technologies of protease production on agrosubstrates

\begin{tabular}{|c|c|c|}
\hline Substrate & Strain-producer & Activity \\
\hline Wheat bran & $\begin{array}{c}\text { Aspergillus awamori MTCC } 6652 \\
\text { Aspergillus flavus MI } 327634 \\
\text { Aspergillus oryzae NRRL } 1808 \\
\text { Aspergillus oryzae } \\
\text { Bacillus amyloliquefaciens } \\
\text { Beauveria felina } \\
\text { Bacillus sp. } \\
\text { Penicillum sp. } \\
\text { Rhizopus oryzae } \\
\text { Rhizopus oryzae } \\
\text { Streptomysec sp. CN } 902\end{array}$ & $\begin{array}{c}1930 \text { units/g } \\
10,5 \text { units/g } \\
31 \text { units/g } \\
1500 \text { units/g } \\
560 \text { units/g } \\
20000 \text { units/g } \\
429 \text { units/g } \\
11000 \text { units/g } \\
58,7 \text { units/g } \\
358 \text { units/g } \\
90,5 \text { units/g }\end{array}$ \\
\hline Rice bran & Aspergillus oryzae NRRL 1808 & 3 units/g \\
\hline $\begin{array}{c}\text { Rice husks + rice } \\
\text { bran }(7: 3)\end{array}$ & Aspergillus oryzae NRRL 2160 & 0,986 units/g \\
\hline $\begin{array}{l}\text { Threshing rice } \\
\text { waste }\end{array}$ & Aspergillus niger MTCC 281 & 67 units/g \\
\hline $\begin{array}{l}\text { Wheat and soy } \\
\text { flour }(1: 1)\end{array}$ & Aspergillus oryzae & 18 units/g \\
\hline Brewer's grain & Bacillus subtilis DL-1 & 528 units/g \\
\hline $\begin{array}{c}\text { Rice bran }+ \text { wheat } \\
\text { bran }(3: 1)\end{array}$ & Aspergillus oryzae (Ozykat-1) & 1200 units/g \\
\hline Whey & Aspergillus terreus & 2,24 units/g \\
\hline $\begin{array}{l}\text { Sweet potato } \\
\text { waste }\end{array}$ & $\begin{array}{l}\text { Aspergillus niger NTU } \\
\text { Aspergillus oryzae NTU } \\
\text { Rhizopus sp. NRRL }\end{array}$ & $\begin{array}{l}837 \text { units/g } \\
809 \text { units/g } \\
900 \text { units/g }\end{array}$ \\
\hline
\end{tabular}

Most publications 1999-2009 period is considering the production of proteases on agrosubstrates using shallow cultivation as a promising direction. Research centers that address the topic, are concentrated in India, Egypt, Thailand, Taiwan, Saudi Arabia and Tunisia. Also, there are publications of Russian researchers. However, most of these technologies is at the stage of laboratory tests. Higher yield of proteases have been reported with wheat bran, and waste processing legumes as a substrate for solid cultivation. As well as a potential raw material for the production of amylase treated agroothody: whey, rice bran, sweet potato processing waste, molasses etc [7]. 
The main task of research is to optimize the protein composition of nutrient medium for cultivation of Bacillus spp. bacteria for the production of proteolytic enzymes.

Materials and methods of researches. For the research minimal salt medium was prepared according the Table 2 .

Table 2

Minimal Salt Medium (Modified from E. Rosenb
\begin{tabular}{|c|c|}
\hline Component & Mass, g \\
\hline $\mathrm{NaCl}_{2}$ & 1,25 \\
\hline $\mathrm{K}_{2} \mathrm{HPO}_{4}$ & 2,37 \\
\hline $\mathrm{KH}_{2} \mathrm{PO}_{4}$ & 0,28 \\
\hline $\mathrm{MgSO}_{4} * 7 \mathrm{H}_{2} \mathrm{O}$ & 0,25 \\
\hline $\mathrm{CaCl}_{2} * \mathrm{H}_{2} \mathrm{O}$ & 0,05 \\
\hline Tap water & 500 \\
\hline
\end{tabular}

The characteristics of agrosubstrates used as protein source of nutrient medium in our research is summarized in Table 3.

Table 3

Objects of the research were protein sources

\begin{tabular}{|c|c|c|c|}
\hline $\begin{array}{c}\text { Name of the protein } \\
\text { source }\end{array}$ & Fats, \% & Protein, \% & Carbohydrates, \% \\
\hline whole-wheat flour & 2 & 9,5 & 71 \\
\hline pea flour & 0,4 & 5,4 & 14,5 \\
\hline phasoleous flour & 2 & 21 & 47 \\
\hline soy flour & 1 & 48,9 & 21,7 \\
\hline wheat bran & 3,2 & 15,5 & 64,5 \\
\hline
\end{tabular}

Bacillus genus bacteria were used as a producers. Bacillus subtilis - Grampositive, rod shaped bacteria, commonly found in soil. Bacillus licheniformis is a Gram-positive, mesophilic bacterium. Its optimal growth temperature is around $30{ }^{\circ} \mathrm{C}$, though it can survive at much higher temperatures.

For our experiment we used surface cultivation. We poured $50 \mathrm{ml}$ of prepared cultural medium into the flasks, then add the different protein sources with different protein concentration which we calculated earlier. The maximum concentration of 
protein was $1 \%$, minimal $-0,1 \%$. The flasks with nutrient media were autoclaved and inoculated with Bacillus spp. bacteria (Fig. 1). The cultivation was conducted at $37^{\circ} \mathrm{C}$ during $48,72,96$ hours.

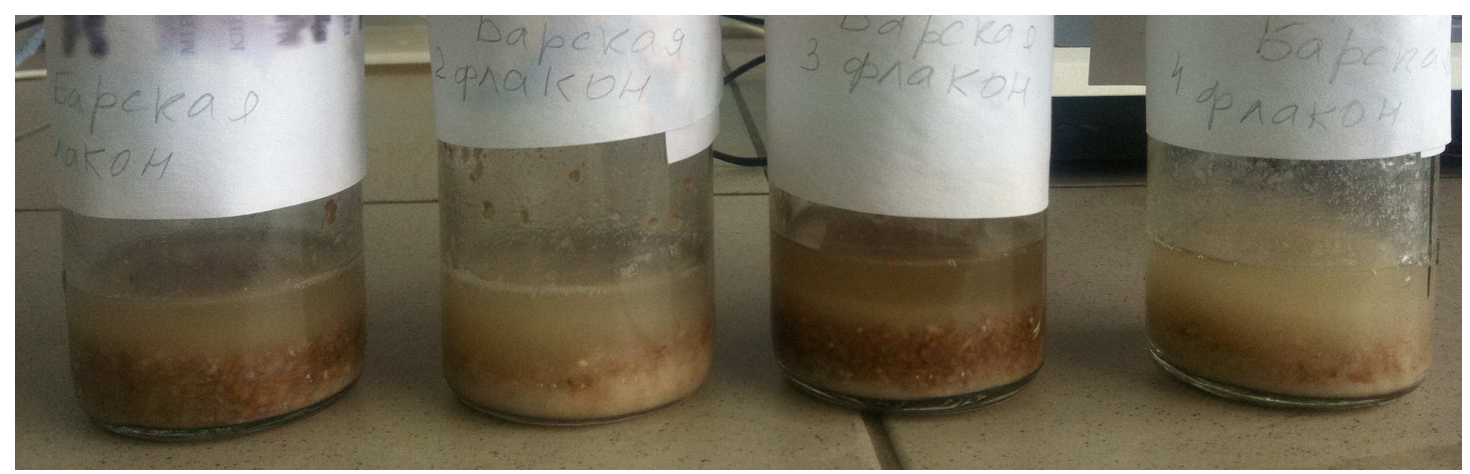

Fig. 1. Flasks with different protein concentration cultural media

Method for enzyme activity determination - spectrophotometric with FolinCiocalteu reagent.

For mathematical methods we used such programs as: Microsoft Excel, Statistica and MathCad.

Results and discussions. We identified the most effective substrates. The data presented in Table 4.

Table 4

Dependence of enzyme activity on the concentration and kind of substrate

\begin{tabular}{|c|c|c|c|c|}
\hline \multirow{2}{*}{\multicolumn{2}{|c|}{ Protein sources }} & \multicolumn{3}{|c|}{ Enzyme activity et different time of cultivation, s.u. } \\
\hline & & 48 hours & 72 hours & 96 hours \\
\hline \multirow{2}{*}{$\begin{array}{l}\text { phasoleous } \\
\text { flour }\end{array}$} & $0,1 \%$ & 49,850 & 33,424 & 22,617 \\
\hline & $1 \%$ & 70,513 & 30,833 & 37,574 \\
\hline \multirow{2}{*}{ pea flour } & $0,1 \%$ & 83,654 & 69,303 & 53,154 \\
\hline & $1 \%$ & 41,205 & 60,484 & 94,186 \\
\hline \multirow{2}{*}{$\begin{array}{l}\text { whole-wheat } \\
\text { flour }\end{array}$} & $0,1 \%$ & 66,882 & 80,455 & 92,214 \\
\hline & $1 \%$ & 33,856 & 20,110 & 14,749 \\
\hline \multirow{2}{*}{ soy flour } & $0,1 \%$ & 35,499 & 53,049 & 70,859 \\
\hline & $1 \%$ & 23,049 & 29,533 & 45,008 \\
\hline \multirow{2}{*}{ wheat bran } & $0,1 \%$ & 27,891 & 70,254 & 20,110 \\
\hline & $1 \%$ & 53,827 & 45,700 & 40,599 \\
\hline
\end{tabular}

From these results it was determined that pea flour, wheat bran and whole-wheat flour have the greatest impact on proteolytic activity of Bacillus genus bacteria. 
Using the Plakett-Bruman method and full factorial analysis we identify two the most profitable substrates - whole-wheat flour and wheat bran by comparing the enzyme activity in the samples with different protein concentrations $(1 \%, 1,5 \%$ and $2 \%)$. Experimental data are shown in the Fig. 2.

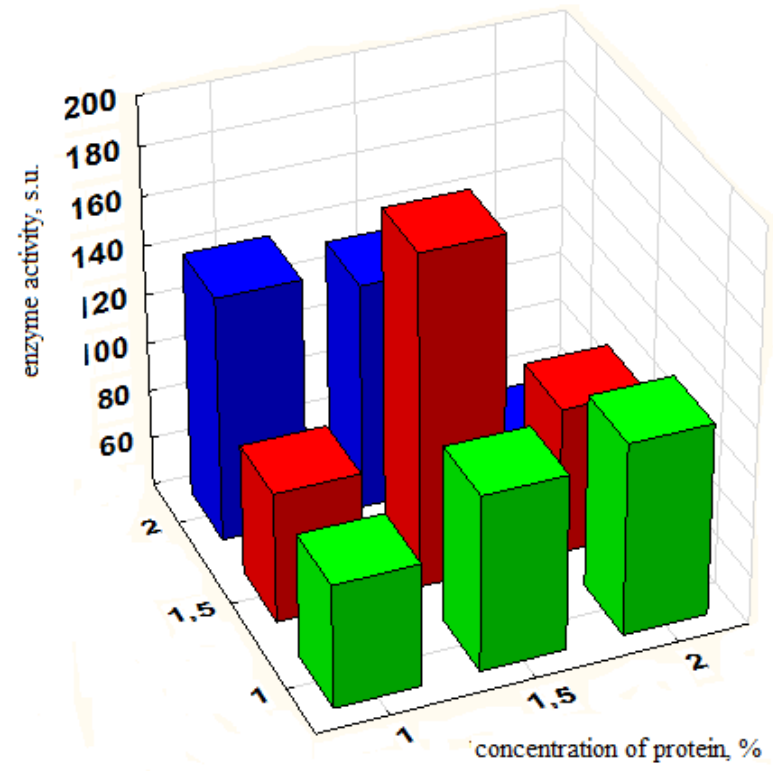

Fig. 2. Dependence of bacteria enzyme activity on protein concentration of whole-wheat flour and wheat bran

After that the mathematical model was built and its shown on the Fig. 3. The equation that shows the dependence of enzyme activity on different protein concentrations was obtained. Model adequacy was checked with the help of $\mathrm{F}$ test.

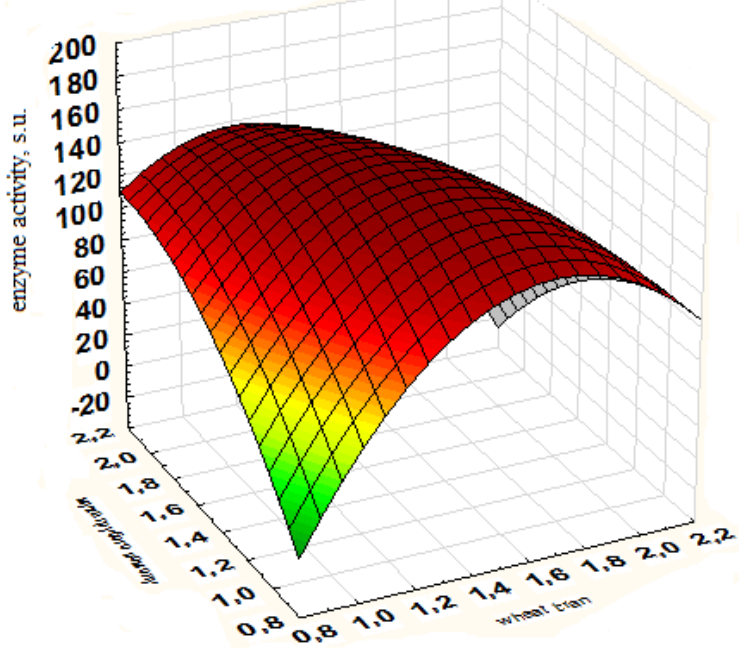

Fig. 3. Mathematic model of the research 
Based on the obtained results using Math Cad we calculated the optimal values of protein concentrations $-1,424 \%$ of wheat bran and 1,529\% of whole-meal flour and got the results shown in Fig. 4.

Target function:

$$
f(x, y):=-588.485+655.0023 \cdot x+346.699 \cdot y-166.65 \cdot x^{2}-114.692 \cdot x \cdot y-57.89 \cdot y^{2}
$$

Initial value: $x:=1 \quad y:=1$

Extremum conditions: $\quad \frac{d}{d x} f(x, y)=0 \quad \frac{d}{d y} f(x, y)=0$

Limitations: $\quad 1 \leq x \leq 2 \quad 1 \leq y \leq 2$

Optimization:

$$
\begin{aligned}
& \operatorname{Maximize}(f, x, y)=\left[\begin{array}{l}
1.418 \\
1.59
\end{array}\right] \\
& f(1.424,1.579)=151.529
\end{aligned}
$$

Value of function under optimal conditions

Fig. 4. Calculations of optimal protein sources concentrations in program MathCad

We found that the highest active proteins observed during 72 hours and with the concentration of protein in the wheat bran $1,4 \%$ and $1,6 \%$ in whole-meal flour.

\section{CONCLUSIONS}

1. The range of economically viable for Ukraine protein substrates was identified that can be used in biotechnology production of proteolytic enzymes, such as wholemeal flour, wheat bran, pea flour phasoleus flour, soy flour.

2. Substrates that most affect the proteolytic activity of the Bacillus spp. were identified. They are whole-meal flour and wheat bran. 
3. A full factorial experiment was performed to determine the optimal ratio of protein components in a nutrient medium.

4. The optimization of microorganisms cultivation parameters was conducted. It was established that the optimum concentrations of wheat bran protein $-1,4 \%$ and whole-meal flour protein $-1,6 \%$ as the main protein source of nutrients medium.

\section{REFERENCES}

1. Birk Y. Plant protease inhibitors / Y. Birk. - NW, USA: CRC Press, 2003 $170 \mathrm{p}$.

2. Katsunuma R. Medical aspects of proteases and proteases inhibitors / R. Katsunuma. - Berlin, Germany: IOS Press, 1997 - 205 p.

3. Lendeckel U. Viral proteases and antiviral protease inhibitor therapy / U. Lendeckel, N. Hooper. - Bellingham WA, USA: Springer, 2009 - 132 p.

4. Polgir L. Mechanisms of protease action / L. Polgir. - Toronto, Canada: CRC PressINC, $1989-223$ p.

5. Carrol T. Germination protease: an atypical aspartic acid protease in Bacillus and Clostridium / T. Carrol. - Norwood MA, USA: ProQuest, 2008 - 141 p.

6. Downess F. Compendium of methods for the microbiological examination of foods / F. Downess. - NW, USA: American public health assosiation, $2001-676$ p.

7. Ratia K. Structure, function and inhibition of the papain-like protease from SARS coronavirus / K. Ratia. - New York, USA: ProQuest, 2008 - 231 p.

\section{ОПТИМІЗАЦІЯ УМОВ КУЛЬТИВУВАННЯ БАКТЕРІЙ РОДУ ВАCILLUS 3 МЕТОЮ ОТРИМАННЯ ПРОТЕОЛІТИЧНИХ ФЕРМЕНТІВ}

\section{С.Г. БАРСЬКА}

Національний авіаційний університет, м. Київ

Визначено спектр економічно доцільних білкових субстратів, що можуть бути використані у біотехнологї отримання протеолітичних ферментів та 
на основі отриманих даних проведено оптимізащію компонентного складу поживного середовища, встановлено максимальну протеолітичну активність бактерій роду Bacillus при їх культивуванні впродовж 72 годин при температурі $37^{\circ} \mathrm{C}$ на поживному середовищі з концентраціями білка висівок1,42 \% та білка муки грубого помолу - 1,58\%.

Ключові слова: бактерії роду Bacillus, субстрати, пшеничні висівки, мука грубого помолу, протеолітичні ферменти, оптимізація.

\section{ОПТИМИЗАЦИЯ ПАРАМЕТРОВ КУЛЬТИВИРОВАНИЯ БАКТЕРИЙ РОДА ВACILLUS ДЛЯ ПОЛУЧЕНИЯ ПРОТЕОЛИТИЧЕСКИХ ФЕРМЕНТОВ}

\section{Е.Г. БАРСКАЯ}

Наџиональный авиаџионный университет, г. Киев

Определен спектр экономически целесообразных белковых субстратов, которые могут быть использованы в биотехнологии получения протеолитических ферментов и на основе полученных данных была проведена оптимизация компонентного состава среды, установлена максимальная протеолитическая активность бактерий рода Bacillus при их культивировании в течении 72 часов при температуре $37{ }^{\circ} \mathrm{C}$ на питательной среде $c$ концентрациями белка пшеничных отрубей - 1,42 \% и белка муки грубого помола $-1,58 \%$.

Ключевые слова: бактерии рода Bacillus, субстраты, пшеничные отруби, мука грубого помола, протеолитические ферменты, оптимизация. 